\title{
PENDEKATAN NEO-VERNAKULAR PADA PERANCANGAN TAMAN BUDAYA KABUPATEN LANDAK KALIMANTAN BARAT
}

\author{
Iqbal Prasetyo \\ Program Studi Arsitektur Fakultas Sains dan \\ Teknologi Universitas Teknologi Yogyakarta \\ e-mail: Iqbal.prasetyo42@gmail.com

\section{Dita Ayu Rani Natalia} \\ Program Studi Arsitektur Fakultas Sains dan \\ Teknologi Universitas Teknologi Yogyakarta \\ e-mail: ditayurani@uty.ac.id
}

\begin{abstract}
ABSTRAK
Taman Budaya merupakan tempat untuk mengembangkan kegiatan seni dan budaya bagi masyarakat di suatu kota atau daerah. Keberadaan Taman Budaya harus terasa bagi masyarakat lokal, namun tidak demikian yang terjadi di Kabupaten Landak, Kalimantan Barat. Di Kabupaten Landak belum tersedia tempat yang dapat menaungi kegiatan seni dan budaya, yang sebetulnya potensi untuk dikembangkan. Hal ini terjadi karena bidang seni dan budaya belum dianggap prioritas. Padahal apabila generasi muda tidak antusias terhadap pengembangan seni budaya, maka akan menjadi masalah cukup besar di masa yang akan datang. Untuk itulah Pemerintah setempat harus menyediakan tempat yang dapat membangkitkan gairah seni dan budaya bagi generasi muda, sekaligus dapat meningkatkan minat wisatawan yang ingin datang ke Kabupaten Landak. Perencanaan Taman Budaya ini menggunakan pendekatan perancangan Neo-Vernakular, khusus nya pada rumah Betang yaitu rumah asli masyarakat Adat Suku Dayak Kanayant, yang menjadi bangunan utama di Taman Budaya ini. Konsep neo-vernakuler dipilih agar nilai kelokalan arsitektur Taman Budaya dapat menjadi ikon atau identitas Kabupaten Landak. Hasil perancangannya adalah Taman Budaya yang mampu memfasilitasi kegiatan seni dan budaya di Kabupaten Landak, sekaligus menjadi ikon pewadahan kegiatan seni dan budaya khususnya adat Dayak.
\end{abstract}

KATA KUNCI: taman budaya, Kabupaten Landak, neo-vernakuler,

\section{PENDAHULUAN}

Taman Budaya merupakan tempat untuk mengembangkan kegiatan seni dan budaya bagi masyarakat di suatu kota atau daerah. Taman budaya berada di bawah naungan Dinas Kebudayaan sebagai fasilitator penyelenggaraan seni dan budaya. Tidak terbatas usia dan profesi, siapapun penggiat seni dapat menggunakan Taman Budaya sebagai tempat pengembangan dirinya.

Kabupaten Landak berada di Provinsi Kalimantan Barat. Kabupaten Landak memiliki kekayaan alam, serta berbagai ragam budaya yang sangat potensial untuk dikembangkan. Mayoritas penduduk adalah etnis Dayak dan etnis Melayu. Penduduk setempat rutin mengadakan event budaya setiap tahun, diantaranya upacara adat Gawai Dayak dan Tumpeng Negeri, Naek Dango untuk adat Melayu. Tradisi tersebut merupakan ungkapan rasa syukur kepada Tuhan atas hasil bumi yang telah dipanen. Di samping itu ada tradisi budaya betungkal, ngancoe aek dan sebagainya. Kebudayaan yang beragam ini sudah semestinya untuk dilestarikan oleh generasi penerus. Mengingat saat ini budaya daerah sudah dipengaruhi arus global, maka jangan sampai tergerus oleh jaman. Perlunya sebuah sarana bagi pengembangan kesenian dan kebudayaan di Kabupaten Landak Kalimantan Barat agar dapat meningkatkan kesadaran terhadap kelestarian budaya yang ada.

Kurangnya minat dan antusias generasi muda akan pengembangan seni dan budaya di Kabupaten Landak menjadi perhatian besar bagi pemerintah setempat, sehingga diperlukan upaya untuk membangkitkan gairah mencintai seni dan budaya tradisi nenek moyang. Pengembangan dan pelestarian potensi budaya Kabupaten Landak memerlukan sebuah tempat, sebagai wadah kegiatan seni dan kebudayaan, berupa sebuah taman budaya.

Pemilihan lokasi tapak sangat diperlukan untuk mewujudkan Taman Budaya sesuai dengan rencana pengembangannya. Lokasi berada di Kota Ngabang, Kabupaten Landak. Pemilihan ini berdasarkan pertimbangan kelebihan serta kekurangan lokasi tapak yang disesuaikan dengan fungsi dari Taman Budaya. Berikut ini beberapa penjelasan mengenai alternatif lokasi tapak dan lokasi terpilih.

\section{Lokasi Pertama}

Lokasi pertama perancangan Taman Budaya Kabupaten Landak terletak di Jalan Raya Ngabang Km 2 (gambar 1). Pertimbangan pemilihan lokasi sebagaimana penjelasan berikut: 


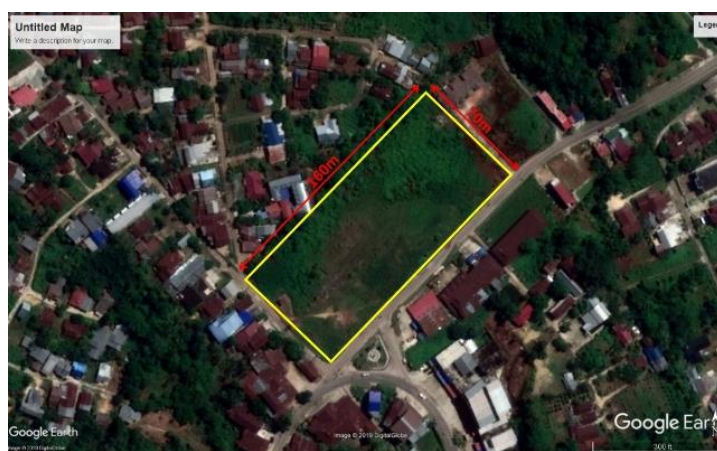

Gambar 1. Alternatif Lokasi Pertama

(Sumber : Analisis Penulis, 2019)

Kelebihan Tapak :

a. Berada pada jalur lintas kabupaten maupun lintas negara yang berpotensi terhadap daya tarik wisatawan yang melintasi jalur tersebut.

b. Kondisi lahan yang cukup besar, terkait fungsi bangunan yang membutuhkan lahan yang cukup besar.

c. Berada pada kawasan pemerintahan yaitu pada koridor pemerintahan segmen 1.

d. Berada pada pusat kota sehingga dengan mudah dapat dijangkau oleh masyarakat perkotaan Ngabang.

e. Dekat dengan Taman Kota (Taman Kota Intan) dan Tugu Kota Intan sebagai icon dari Kabupaten Landak.

f. Kondisi lahan hijau pada area sekitar tapak masih cukup banyak.

Kekurangan Tapak :

a. Berada pada banyak persimpangan jalan, yang berdampak pada penyebab kemacetan yang akan ditimbulkan.

b. Kurang baiknya saluran drainase pada lokasi tapak.

\section{Lokasi Kedua}

Lokasi kedua untuk perancangan Taman Budaya Kabupaten Landak terletak di Jalan Afandirani (gambar 2). Adapun petimbangan dari pemilihan lokasi sebagai berikut:

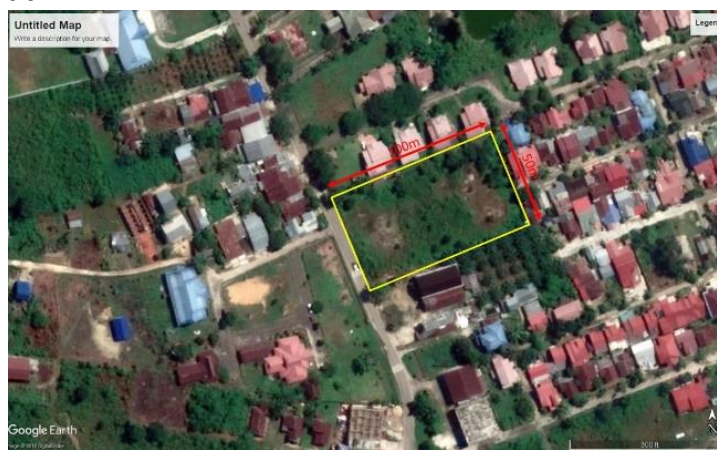

Gambar 2. Alternatif Lokasi Perancangan Kedua (Sumber : Analisis Penulis, 2019)
Kelebihan Tapak :

a. Cukup dekat dengan salah satu bangunan cagar budaya sebagai penunjang dari kegiatan pada fungsi bangunan.

b. Berada pada kawasan pemerintahan yaitu pada koridor pemerintahan segmen 3 .

c. Berada pada kawasan perdagangan dan jasa serta beberapa caffe yang dapat menarik minat pengunjung.

Kekurangan Tapak :

a. Dekat dengan pemukiman warga yang berdampak pada kebisingan yang ditimbulkan dari fungsi bangunan.

b. Kondisi lahan yang cukup kecil, sehingga tidak sesuai dengan kubutuhan fungsi bangunan perancangan.

c. Bersebelahan dengan bangunan ibadah (Bangunan Gereja)

d. Kurang baiknya saluran drainase pada lokasi tapak.

Ngabang adalah sebuah kecamatan di Kabupaten Landak, Provinsi Kalimantan Barat, Indonesia. Kecamatan Ngabang merupakan ibu kota Kabupaten Landak sehingga semua jenis aktivitas ekonomi, fasilitas umum dan transportasi serta pemerintahan Kabupaten Landak berpusat di wilayah ini. Luas wilayahnya $1.148,10 \mathrm{~km}^{2}$, dan jumlah penduduknya 65.552 jiwa. Di tengah kota mengalir sebuah sungai yaitu Sungai Landak yang membelah pusat Kota Ngabang. Jarak Kota Ngabang berjarak 81 $\mathrm{Km}$ ke arah timur laut dari Pontianak. Kota Ngabang dilintasi dua jalur vital yakni Jalan Trans Kalimantan serta Jalan Lintas Negara. Di atas Sungai Landak juga terdapat dua buah jembatan yang menghubungkan antara kedua daerah yakni Ngabang Barat dan Timur.

\section{Lokasi Terpilih}

Berdasarkan kajian pemilihan lokasi, skoring site digunakan untuk menentukan beberapa titik lokasi alternatif yang memiliki potensi dan akan dijadikan sebagai lokasi perancangan secara makro dan mikro.

Adapun alternatif site yang digunakan untuk perancangan di Ngabang Kabupaten Landak, dinilai berdasarkan beberapa parameter sebagaimana dalam tabel 1.

Tabel 1. Parameter dan penilaian lokasi

\begin{tabular}{clcc} 
No & \multicolumn{1}{c}{ Indikator } & Site 1 & Site 2 \\
\hline 1 & Pencapaian Ke Site & 4 & 4 \\
\hline 2 & Sirkulasi Pejalan Kaki & 2 & 2 \\
\hline 3 & Sirkulasi Kendaraan & 4 & 4 \\
4 & View Keluar Site & 4 & 3 \\
\hline 5 & View Kedalam Site & 4 & 3 \\
\hline 6 & Luasan Site & 4 & 2 \\
\hline
\end{tabular}




\begin{tabular}{|c|c|c|c|}
\hline No & Indikator & Site 1 & Site 2 \\
\hline 7 & Fasilitas Umum & 4 & 2 \\
\hline 8 & Utilitas Kawasan & 4 & 3 \\
\hline 9 & Topografi & 4 & 4 \\
\hline 10 & Potensi Wisata & 4 & 2 \\
\hline 11 & Keunikan Site & 4 & 2 \\
\hline & Jumlah & 42 & 31 \\
\hline
\end{tabular}

(Sumber : Analisis penulis, 2019)

Keterangan : 1. Kurang, 2 Cukup, 3 Baik, 4 Sangat baik.

Berdasarkan point dari parameter tabel skoring di atas maka site terpilih adalah alternatif 1 sebagai lokasi Perancangan Taman Budaya Kabupaten Landak Kalimantan Barat.

\section{METODE PERANCANGAN}

Perancangan bangunan ini menggunakan metode deskriptif analisis dengan pendekatan disain arsitektur neo-vernakuler. Metode deskriptif analisis berupa paparan/deskripsi yang terjadi saat ini disertai dengan literatur-literatur yang mendukung teori-teori perancangan yang digunakan.

Analisa data dilakukan secara kualitatif deskriptif, yang membahas teknik pengumpulan, pengolahan atau analisa dan penyajian terhadap sekelompok data. Analisis data secara kualitatif dilakukan berdasarkan logika dan argumentasi yang bersifat ilmiah. Langkahlangkah ini meliputi survey objek-objek komparasi, lokasi tapak untuk mendapatkan data-data dan komparasi yang berhubungan dengan objek perancangan.

Kerangka berfikir dalam perancangan Taman Budaya Kabupaten Landak Kalimantan Barat diuraikan dalam beberapa tahap sebagai berikut:

1) Proses pencarian ide

Proses pencarian ide menyesuaikan informasi seberapa besar peluang perancangan Taman Budaya Kabupaten Landak Kalimantan Barat melalui pendekatan Neo-Vernakular, yang dapat mengakomodasi kegiatan seni dan budaya yang ada.

2) Proses pemecahan masalah

Pemantapan ide perancangan melalui penelusuran informasi dan data-data arsitektural maupun non-arsitektural dari berbagai pustaka dan media sebagai bahan perbandingan dalam pemecahan masalah.

3) Proses menuangkan ide

Merupakan proses pengembangan ide perancangan yang telah diperoleh, yang kemudian diekspresikan dalam bentuk sebuah gambar disain.

\section{ANALISA DAN PEMBAHASAN}

Pertimbangan lokasi terpilih untuk Perancangan Taman Budaya Kabupaten Landak berdasarkan kriteria sebagai berikut:

1) Kelancaran aksesibilitas kendaraan yang berada di sekitar lokasi perancangan agar dapat memudahkan keluar masuknya pengunjung, pengelola maupun servis.

2) Daya tarik dari bangunan yang dapat mempengaruhi minat pegunjung.

3) Luasan lahan yang cukup besar terkait dengan fungsi dari pertunjukan seni budaya yang memerlukan space yang cukup besar.

4) Lokasi parkir yang cukup luas agar tidak mengganggu aksesibilitas pada area bangunan.

5) Kondisi struktur tanah perlu dianalisis agar dapat menentukan jenis struktur yang sesuai dengan lokasi perancangan.

6) Kelengkapan utilitas pada bangunan yang disesuaikan dengan kebutuhan terkait dengan fungsi bangunan dengan kepadatan pengunjung yang cukup tinggi.

Adapun data lahan atau lokasi sebagai berikut :

1) Kota/Kecamatan : Ngabang

2) KDB dan KLB : $50 \%$ dan $200 \%$

3) GSB Jl. Km $2: 5$ meter

4) GSB Jl. Riasinir : 3 meter

5) Fungsi Lahan : Koridor Pemerintahan Segmen 1

6) Total luasan lahan : $11.200 \mathrm{~m}^{2}$

7) Batas geografis tapak (lihat gambar 3)

Sebelah Utara : Kawasan Pemukiman dan Lahan Kosong

Sebelah Timur : Kawasan Perdagangan dan Jasa Sebelah Barat : Kawasan Pemukiman dan Lahan Kosong

Sebelah Selatan : Kawasan Perdagangan dan Jasa

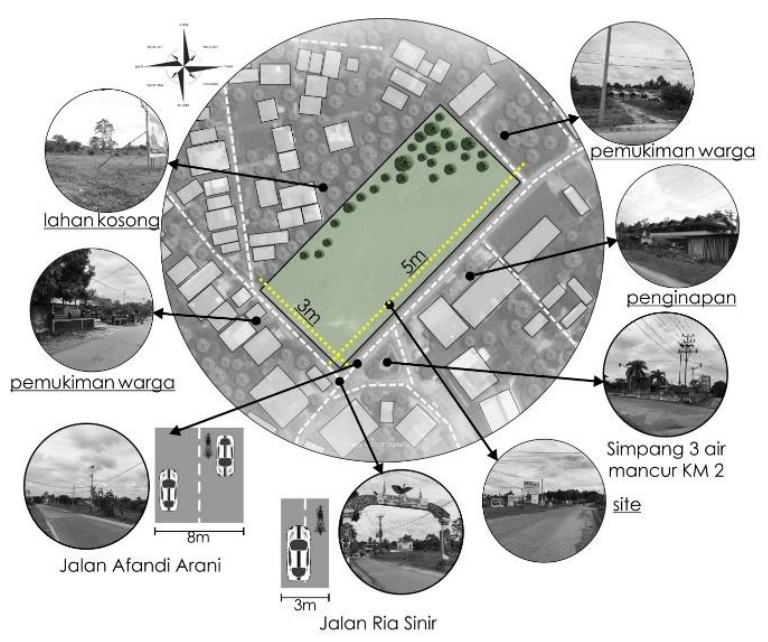

Gambar 3. Data Site

(Sumber : Analisis penulis, 2019) 

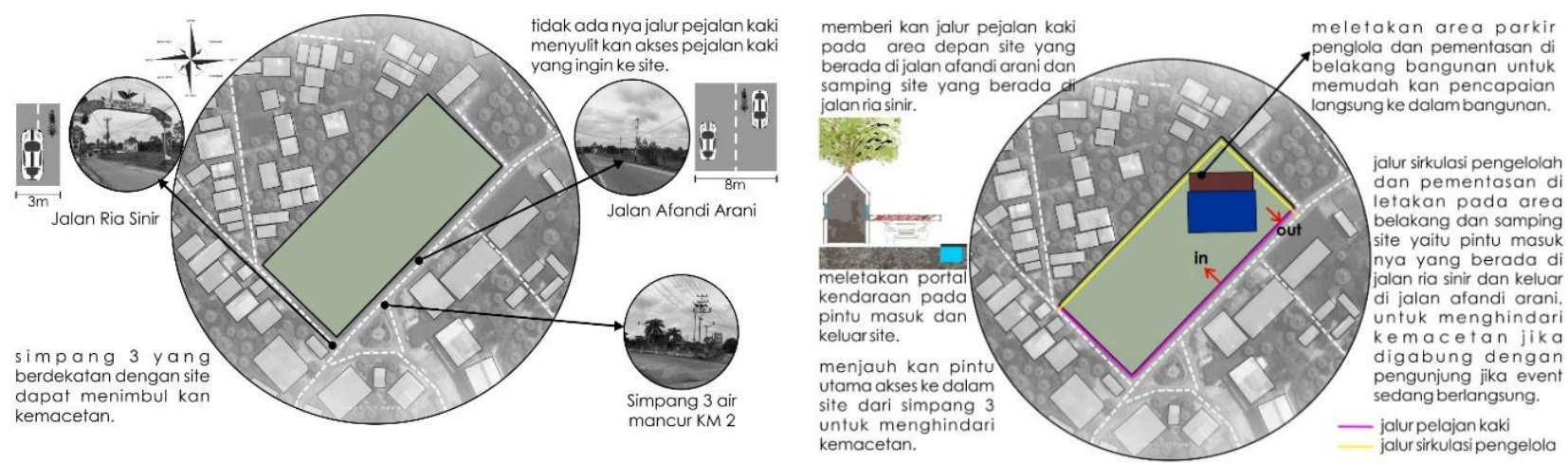

Gambar 4. Analisis Aksesibilitas (data dan respon) (Sumber : Analisis penulis 2019)

\section{Analisa Makro}

1). Analisa Aksesibilitas

Analisa aksesibilitas untuk menentukan akses atau alur keluar dan masuk ke dalam site bagi pengendara (gambar 4).

2) Analisa Utilitas

Analisa utilitas untuk mengetahui jaringan utilitas seperti selokan, tiang listrik dan gardu yang ada di sekitar site dan diperlukan dalam perancangan (gambar 5)

\section{Analisa Mikro}

1) Analisa Angin

Analisa angin berguna untuk mengetahui arah datang nya angin sebagai pertimbangan ada nya bukaan pada bangunan sebagai penghawaan alami (gambar 6).

2) Analisa View

Analisa view untuk menentukan arah bangunan agar mudah dikenali dan view yang bagus untuk arah pada fasad bangunan (gambar 7).
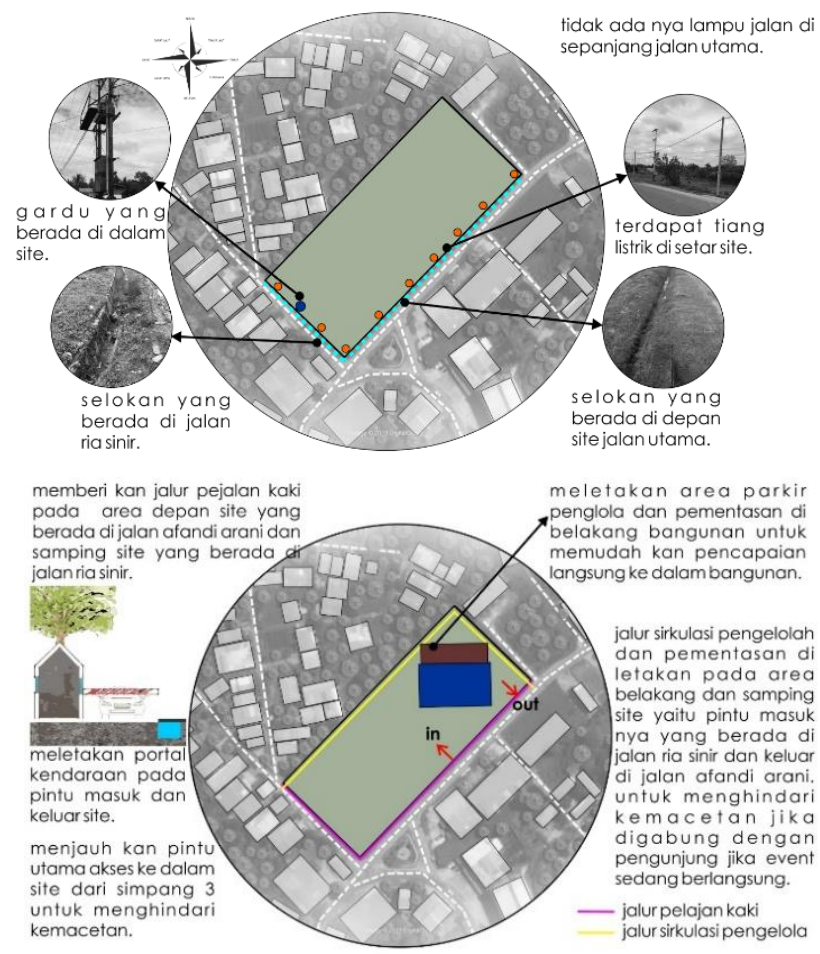

Gambar 5. Analisis utilitas (data dan respon) (Sumber : Analisis penulis 2019)
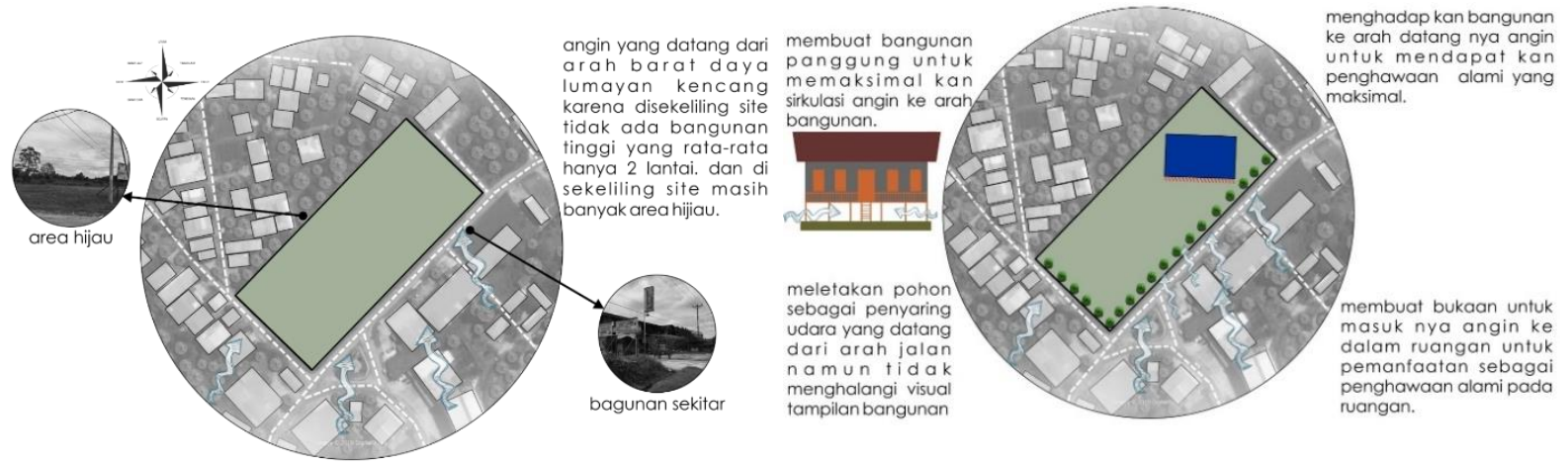

Gambar 6. Analisis angin (data dan respon)

(Sumber : Analisis penulis 2019) 

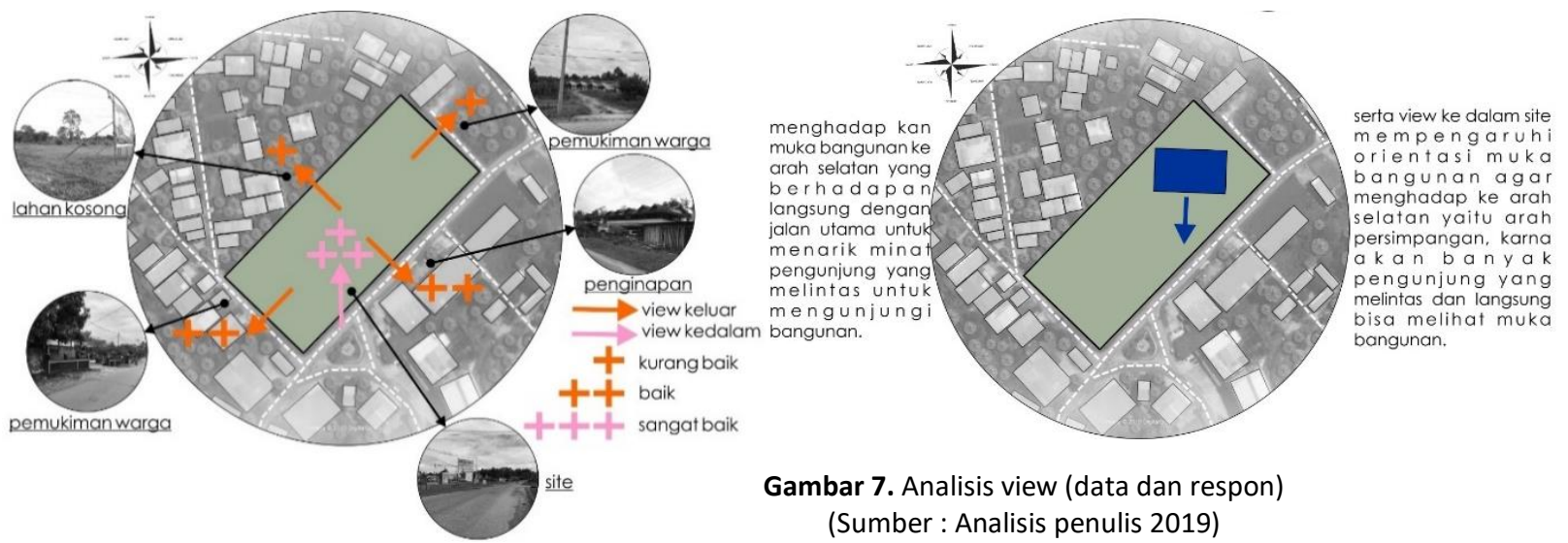

Gambar 7. Analisis view (data dan respon)

(Sumber : Analisis penulis 2019)
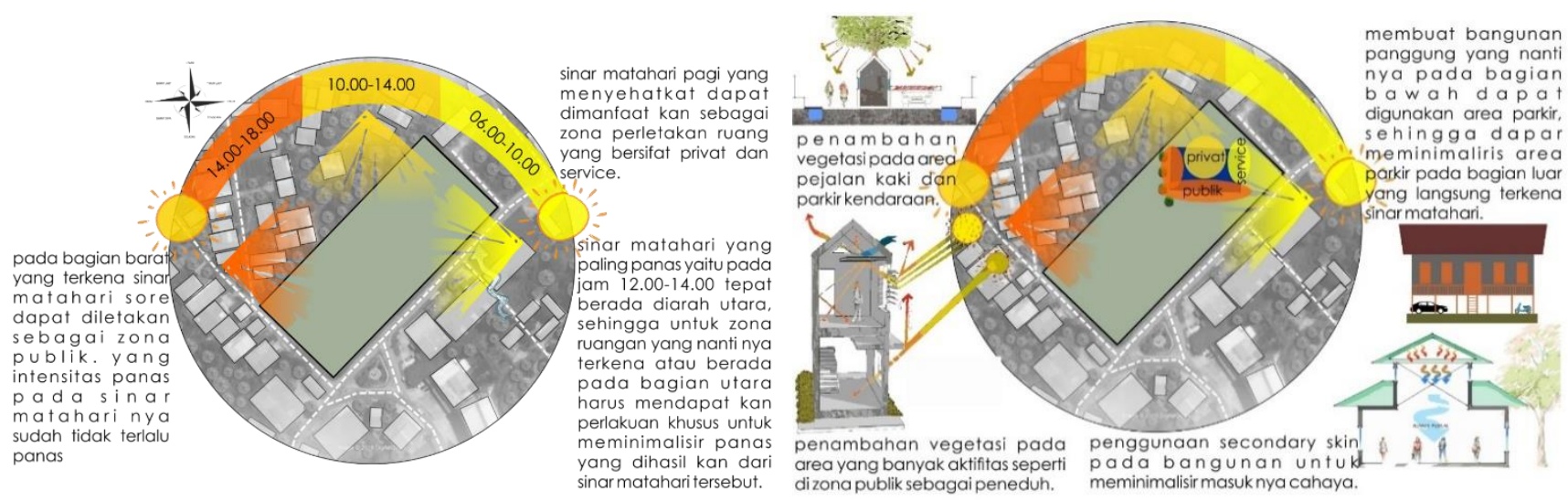

Gambar 8. Analisis matahari (data dan respon)

(Sumber : Analisis penulis 2019)
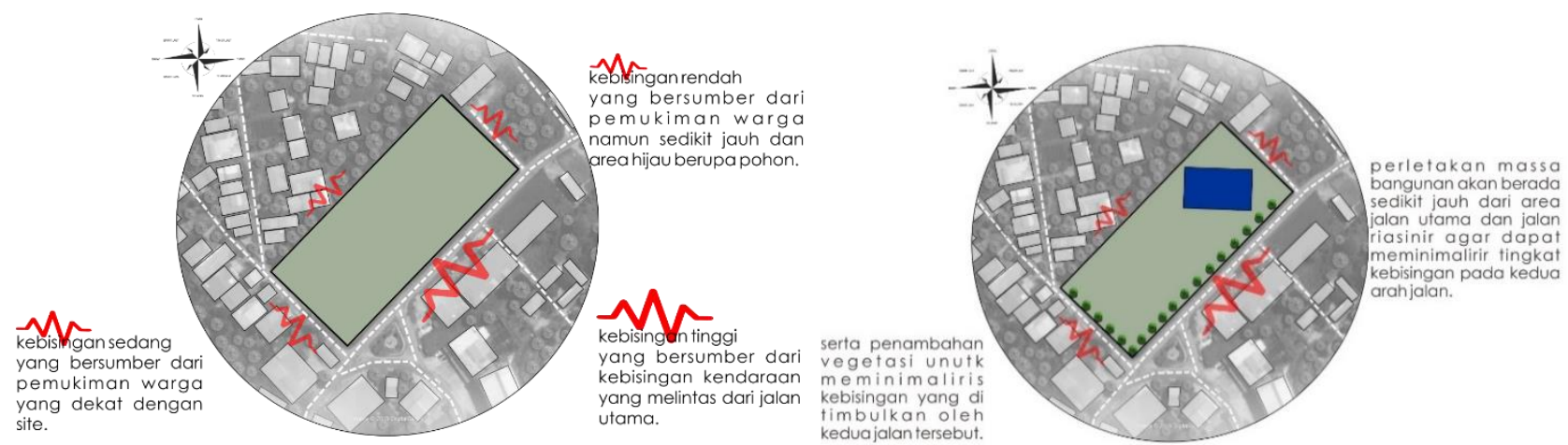

Gambar 9. Analisis kebisingan (data dan respon)

(Sumber : Analisis penulis, 2019)

3) Analisa Matahari

Analisa matahari untuk mengetahui perletakan pada fungsi ruang bangunan yang ada dan pertimbangan pada bukaan yang nanti nya ada di bangunan (lihat gambar 8).

4) Analisa Kebisingan

Analisa kebisingan untuk mementukan perletakan bangunan yang baik agar terhindar dari kebisingan yang ditimbul kan dari sekitar site (gambar 9).

\section{PROGRAMING}

Pelaku kegiatan merupakan orang yang terlibat dan berperan dalam segala kegiatan di dalam disain Taman Budaya, yang terdiri dari 3 pelaku kegiatan yaitu, pengelola, pengunjung dan pemain/pementas. Berikut penjelasan dari pelaku kegiatan :

1) Pengelola adalah serangkaian aktivitas koordinasi yang mencakup perencanaan, pengorganisasian, 
pengarahan, pengendalian, penempatan serta pengambilan keputusan untuk menghasilkan suatu produk dan jasa yang efektif dan efesien (Andrew F Sikula, 2011)). UPT merupakan singkatan dari Unit Pelaksanaan Teknis yang mencakup salah satu item unit kegiatan dari Dinas Pendidikan dan Kebudayan Kabupaten Landak (gambar 10).

a. Kepala UPT : Memimpin dan bertanggung jawab penuh

b. Kepala dan Staff Tata Usaha : Mengelola pernyusunan, pelayanan adminis

c. Kepala dan Staff Humas : Mengelola publikasi, dokumentasi

d. Staff Fungsional : Mengelola dan mengevaluasi pementasan

e. Staff Kebersihan : Mengelola kebersihan gedung

f. Staff Keamanan : Menjaga keamanan

g. Staff Teknisi : Menyediakan, mengecek keperluan teknisi

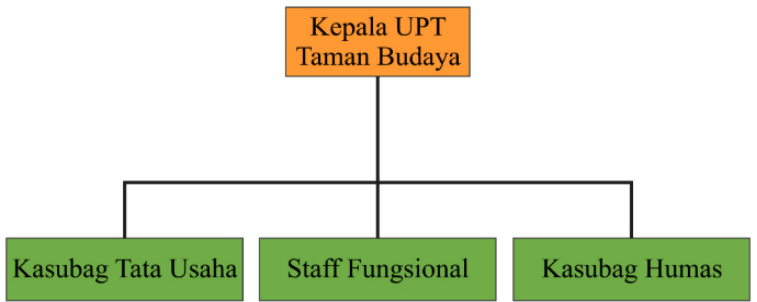

Gambar 10. Struktur Organisasi Pengelola

2) Pengunjung adalah kelompok orang yang ingin menyaksikan pertunjukan yang sedang berlangsung.

3) Pemain/pementas adalah kelompok orang yang melakukan pementasan pada pertunjukan tersebut.

Kebutuhan ruang muncul dari hasil analisa pengguna beserta aktifitasnya yang harus diwadahi dan difasilitasi yang kemudian akan disesuaikan dengan kondisi eksisting. Setelah diketahui pelaku dan kebutuhan ruang yang diperlukan, selanjutnya dilakukan analisis persyaratan ruang yang disesuaikan standar kenyamanan baik dari segi pencahayaan, penghawaan maupun akustika ruangan. Setelah mengetahui persyaratan ruang yang dibutuhkan sesuai dengan ketetapan standar maka tahapan selanjutnya yaitu analisis hubungan ruang. Ruang yang telah didapatkan memiliki keterkaitan satu sama lain, maka dibutuhkan analisis hubungan ruang. Analisis ini berfungsi untuk mengatahui kedekatan ruang berdasarkan fungsi, sifat dan kriteria ruang.

Analisis hubungan ruang di atas, maka bisa didapatkan hubungan ruang yang akan digunakan dalam perancangan pengorganisasian ruang pada bangunan. Analisis organisai ruang terbagi menjadi empat fungsi, yaitu fungsi penerima, fungsi pengelola, fungsi pemain/pementas dan fungsi pelayanan.

Besaran ruang diperoleh dari hasil perkalian dimensi setiap perabot yang telah ditetapkan standar dimensinya (Neufert, Ernst 2002), kemudian dijumlahkan dan ditambahkan dengan sirkulasi yang diasusmsinya $25 \%$ dari total keseluruhan. Semua ruang telah dirincikan berdasarkan kebutuhan perabot dan jumlah pelakunya. Berdasarkan perhitungan yang telah dijabarkan dari masing-masing fungsi ruang didapatkan sub total besaran ruang berdasarkan kelompok fungsi berikut ini sub total berdasarkan kelompok fungsi :
a. Fungsi Pengelola
$=282,25 \mathrm{~m}^{2}$
b. Fungsi Pengunjung
$=1.825,66 \mathrm{~m}^{2}$
c. Fungsi Pemain/Pementas
$=353,34 \mathrm{~m}^{2}$
d. Fungsi Servis
Total luasannya yaitu
$=93,75 \mathrm{~m}^{2}+$
$=2555,00 \mathrm{~m}^{2}$

\section{KONSEP DESAIN}

\section{Konsep gubahan}

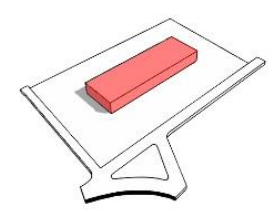

memanjang mengikuti site.

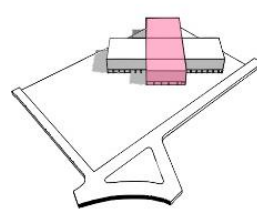

penambahan gubahan mas

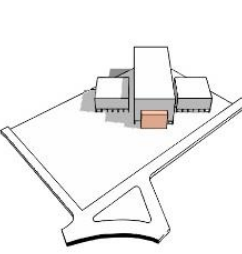

pe $n a m b$ a h a n gubahan pada bagian dan dropoff.

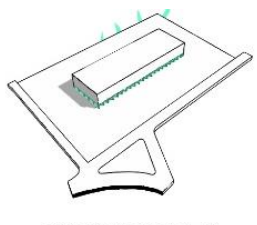

gubahan masa di

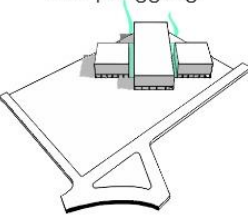

gubahan masa di pecah untuk sirkuliasi angin.

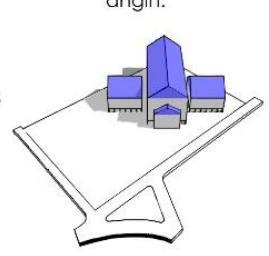

atap pelana arah gubahan masa

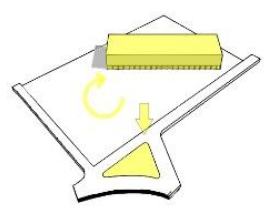
tiga.

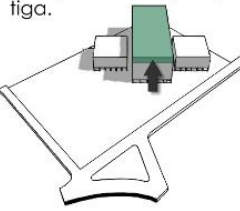
bagian tengah di tinggi kan karna memilki kan karna memiliki 2 lantai.

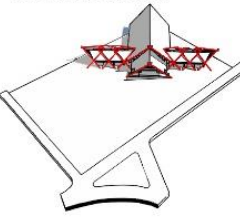

rangka yang yang ang menyelimu gubahan masa. masa bangunan pada

Gambar 11. Konsep Gubahan

(Sumber : Analisis penulis, 2019)

\section{Konsep bentuk dan fasad}

Konsep bentuk keseluruhan menerapkan komponen-komponen dari rumah Betang yang diaplikasikan dari hasil breakdown pendekatan NeoVernakular yang dipecah menjadi 3 yaitu prinsip, filosofi dan teknologi sebagai berikut:

\section{Prinsip}


Melestarikan unsur-unsur lokal yang telah terbentuk oleh tradisi dan mengembangkannya menjadi suatu langgam yang modern. Kelanjutan dari arsitektur vernaKular.

\section{a. Matahari}

Masyarakat suku Dayak mempercayai matahari terbit merupakan kehidupan dan matahari tenggelam sebagai kematian. Hal ini dianggap sebagai simbol dari kerja keras untuk bertahan hidup mulai dari matahari terbit hingga terbenam.

\section{b. Zonasi}

Dalam simbol presentatif bentuk bangunan rumah Betang yaitu atap hubungannya antara manusia dengan tuhan, bagian tengah hubungan manusia dengan manusia dan bagian bawah hubungan manusia dengan alam. Untuk ruangan dibagi menjadi beberapa bagian berdasarkan kegunaan dan fungsinya masing-masing: Pante (Teras), Samik (Ruang Tamu), Padong (Ruang Keluarga), Bilik (kamar), Dapur.

\section{Filosofi}

Lebih mementingkan fasad atau bentuk, ornamen sebagai suatu keharusan.

\section{a. Sosial}

Masyarakat suku Dayak yang berpegang teguh pada "Adil Ka' Talino, Bacuramin Ka' Saruga, Basengat Ka' Jubata" yang arti nya bahwa dalam hidup ini kita harus bersikap adil, jujur tidak diskriminatif terhadap sesama manusia, dengan mengedepankan perbuatan-perbuatan baik seperti di surga berdasarkan ketuhanan yang maha esa.

b. Sungai

Sungai merupakan jalur transportasi utama masyarakat suku Dayak.

c. Warna

Warna pada suku Dayak adalah hitam, putih, merah dan kuning yang memiliki makna masing-masing, hitam sebagai warna penangkal agar terhindar dari gangguan roh halus, putih memiliki makna sebagai simbol kesucian, merah memiliki makna keberanian dan kuning memiliki makna tata krama.

\section{Teknologi}

Bentuk desain lebih modern.

\section{a. Bentuk}

Panjang rumah betang mencapai 150 meter, lebar 30 meter dan tinggi panggung sekitar 3 meter. Tangga yang berjumlah ganjil. Atap rumah berbentuk pelana memanjang. Atap rumah betang tidak memiliki makna yang spesifik, maknanya sesuai atap pada umumnya yaitu manaungi.

\section{b. Ornamen}

Ornamen burung pada setiap sudut atap pada rumah betang. Perisai atau gunamp barote' istilah dalam bahasa Dayak Kanayant bermakna lukisan yang memberikan tempat berlindung.

\section{c. Material}

Rumah Betang di bangun menggunakan bahan kayu yang berkualitas tinggi, yaitu kayu ulin, selain memiliki kekuatan yang bisa berdiri sampai dengan ratusan tahun, kayu ini juga anti rayap.

Hasil dari breakdown di atas diperoleh beberapa point yang diterapkan pada desain (gambar 12-15).

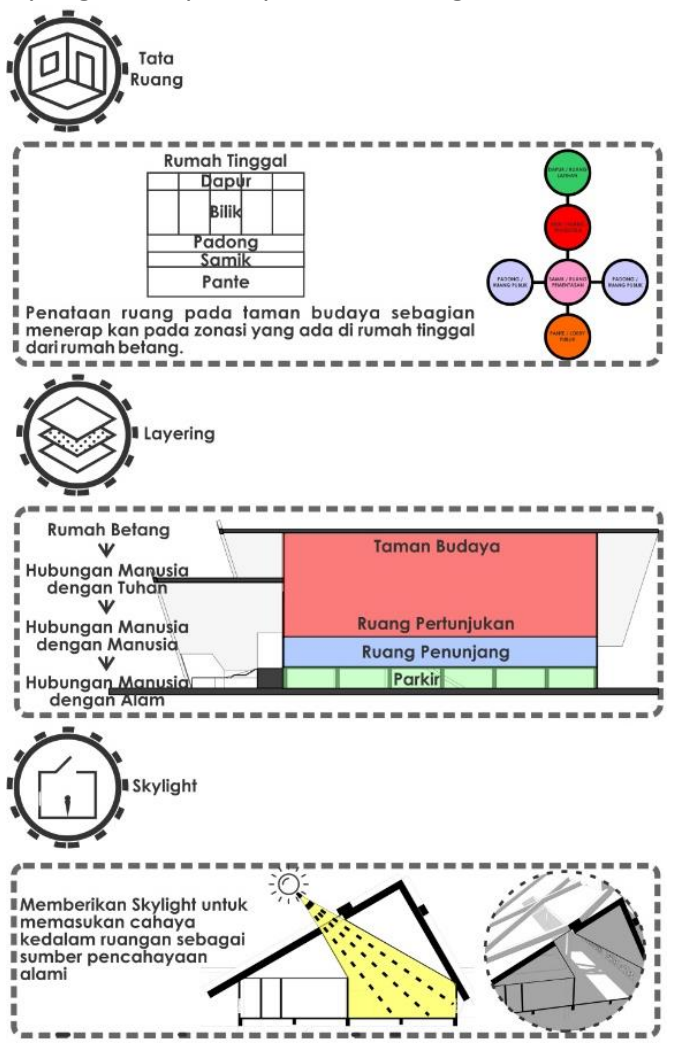

Gambar 12. Tata ruang, Layering dan Skylight (prinsip) (Sumber : Analisis penulis, 2019)

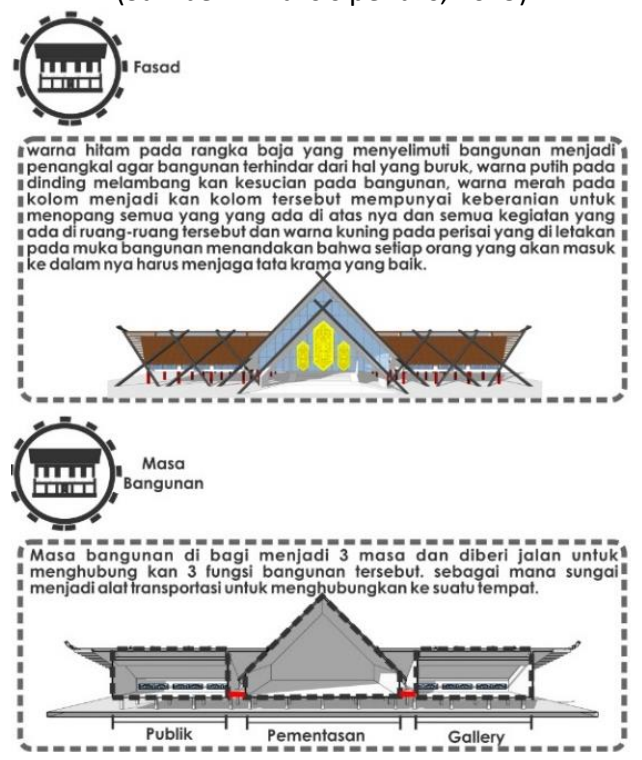




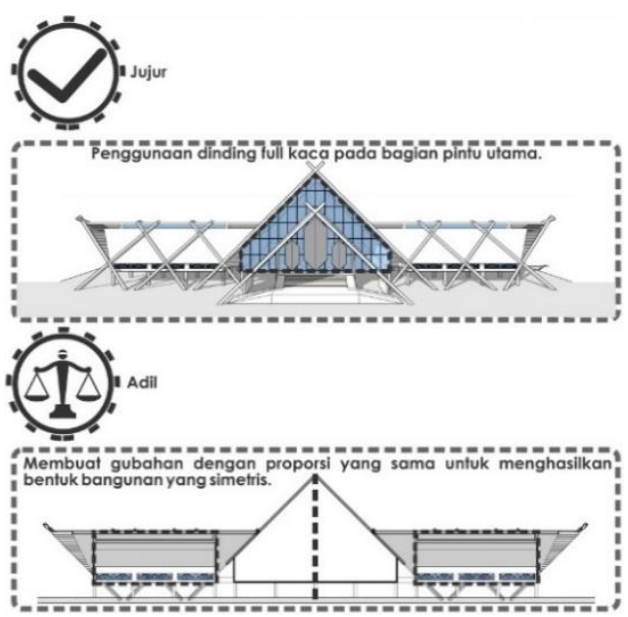

Gambar 13. Fasad, Masa Bangunan, Jujur dan Adil (Filosofi) (Sumber : Analisis penulis, 2019
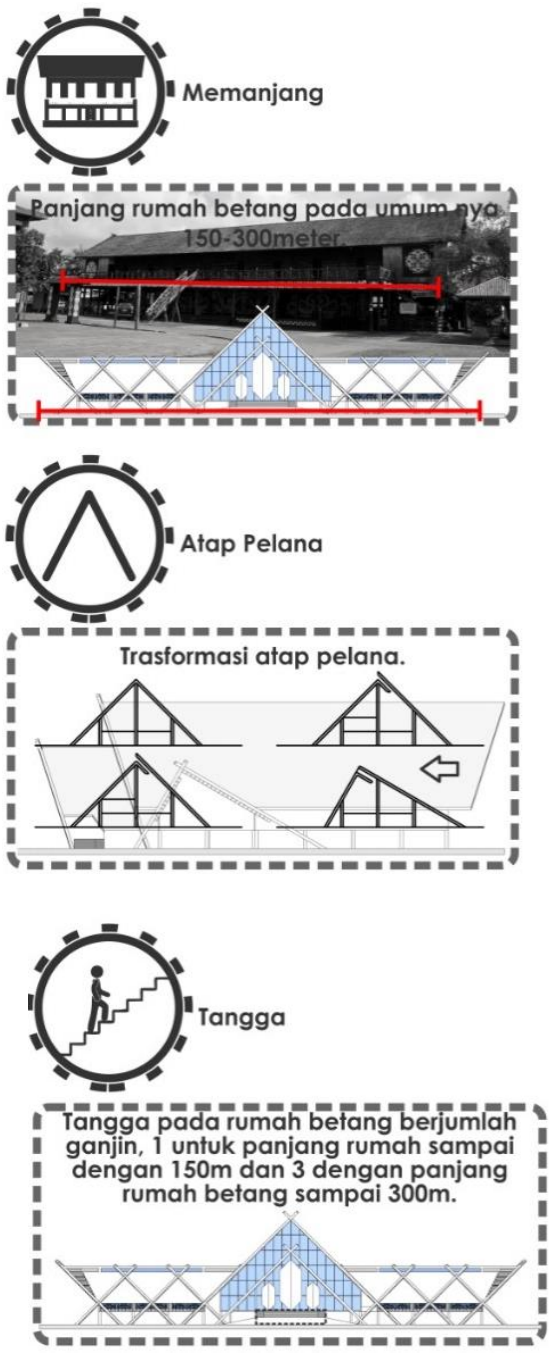

Gambar 14. Memanjang, Atap Pelana dan Tangga (teknologi)

(Sumber : Analisis penulis, 2019)
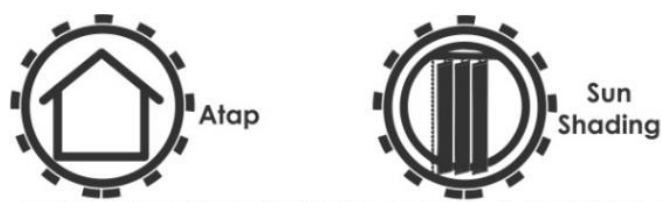

Or a m e B r ung Sun Shading dibuat seperti Enggang dan palang silangl Ibilik-bilik atau jendela dis setiap ujung atap.
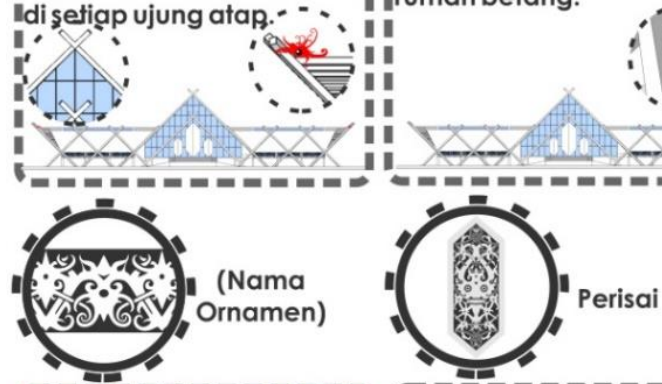

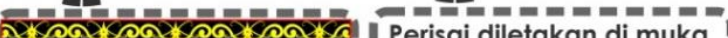
Or $\mathrm{n}$ a m e $\mathrm{D}$ a y a $\mathrm{k}$ I lbangunan menjadikan IKanayant di letakan padal Iperisai sebagai identitgs Ikolom dan jendela. I Ibangunan.
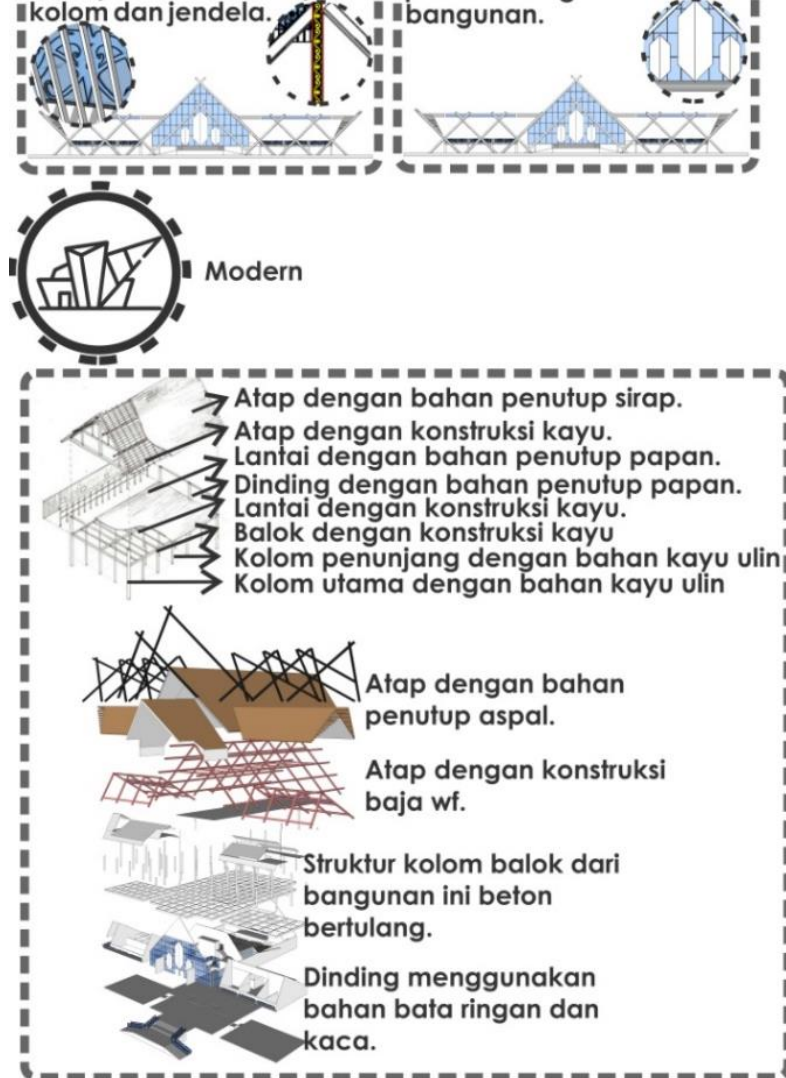

Gambar 15. Ornamen dan Struktur (Teknologi)

(Sumber: Analisis penulis, 2019)

\section{Konsep site}

Menunjukan tata letak seperti parkir dan jalur sirkulasi kendaraan dan pejalan kaki yang ada di site (lihat gambar 16-23). 


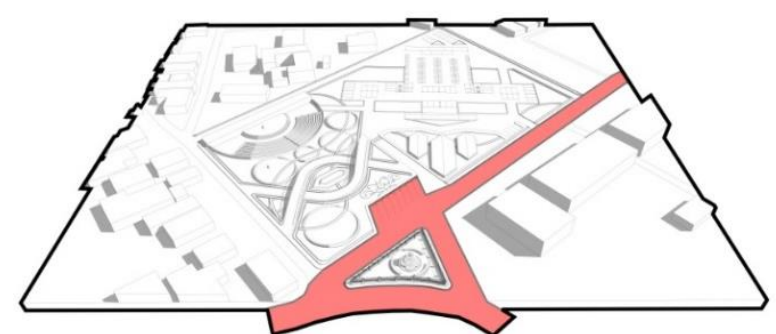

jalur sirkulasi bus, parkir bus di letakan pada pinggir jalan utama.

Gambar 16. Sirkulasi Bus (sumber: analisis penulis, 2019)

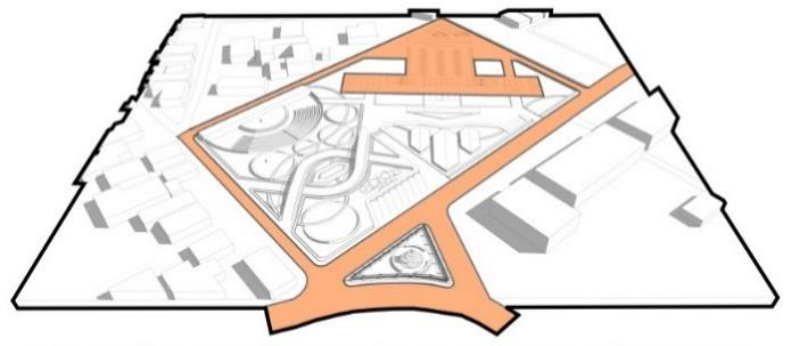

jalur sirkulasi pengelola, service dan pementas. jalur masuk terletak pada belakang site di jalan ria sinir.

Gambar 17. Sirkulasi Service

(sumber: analisis penulis, 2019)

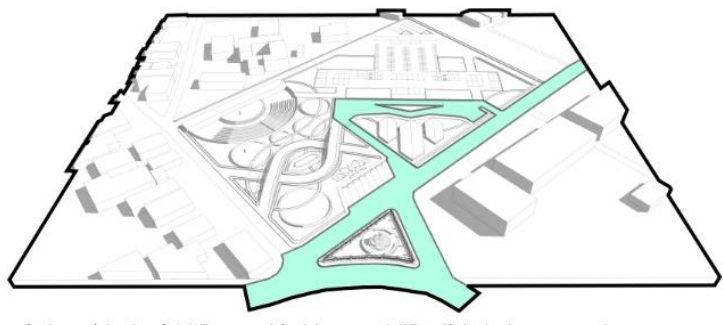

jalur sirkulasi VIP, parkir khusus VIP di letakan pada area depan untuk memudahkan sirkulasi ke drop off.

Gambar 18. Sirkulasi VIP

(sumber: analisis penulis, 2019)

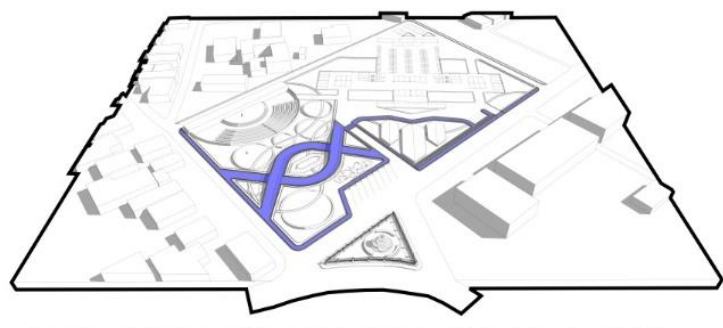

jalur pedestrian di luar site berada di pinggir jalan utama dan ria sinir serta jalur pedestrian di dalam site untuk memudah kan akses pejalan khaki ke bangunan.

Gambar 19. Sirkulasi pedestrian (sumber: analisis penulis, 2019)

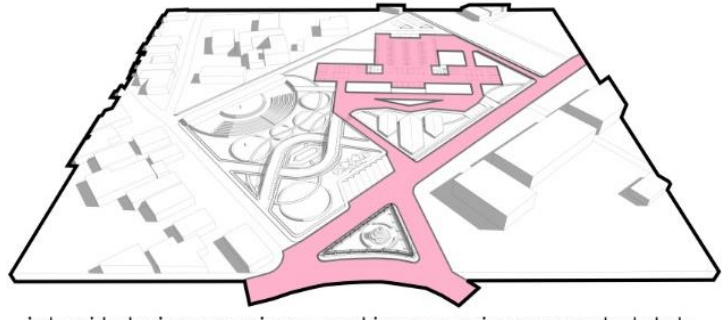

jalur sirkulasi pengunjung, parkir pengunjung yang terletak pada bagian panggung bangunan. untuk jalur keluar pengunjung di beda kan pada jalur keluar VIP.

Gambar 20. Sirkulasi umum (sumber: analisis penulis, 2019)

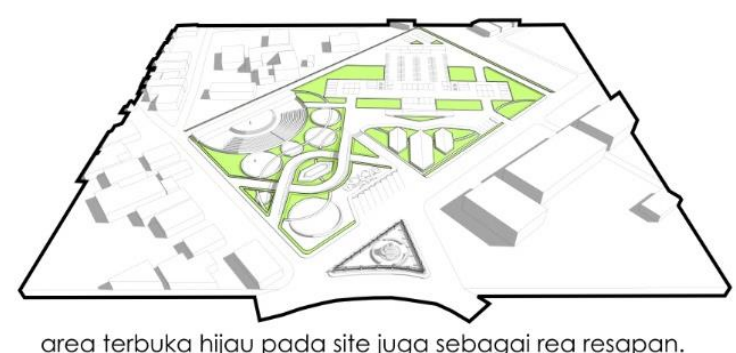

area terbuka hijau pada site juga sebagai rea resapan.

Gambar 21. Area hijau (sumber: analisis penulis, 2019)

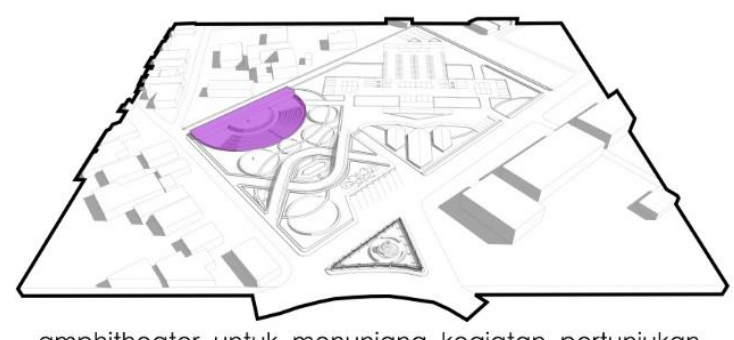

amphitheater untuk menunjang kegiatan pertunjukan outdoor.

Gambar 22. Amphiteater

(sumber: analisis penulis, 2019)

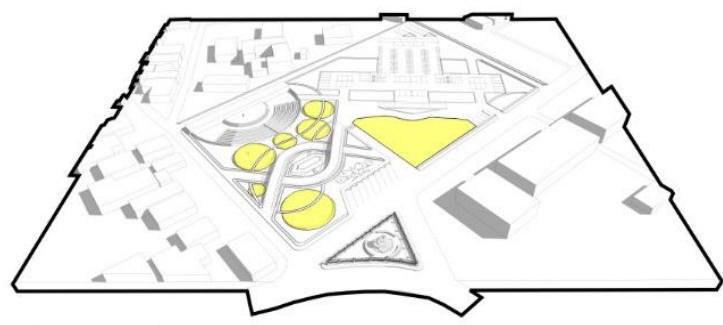

Area Terbuka dan lapangan kirap

Gambar 23. Area terbuka dan lapangan kirab (sumber: analisis penulis, 2019) 


\section{Konsep struktur}

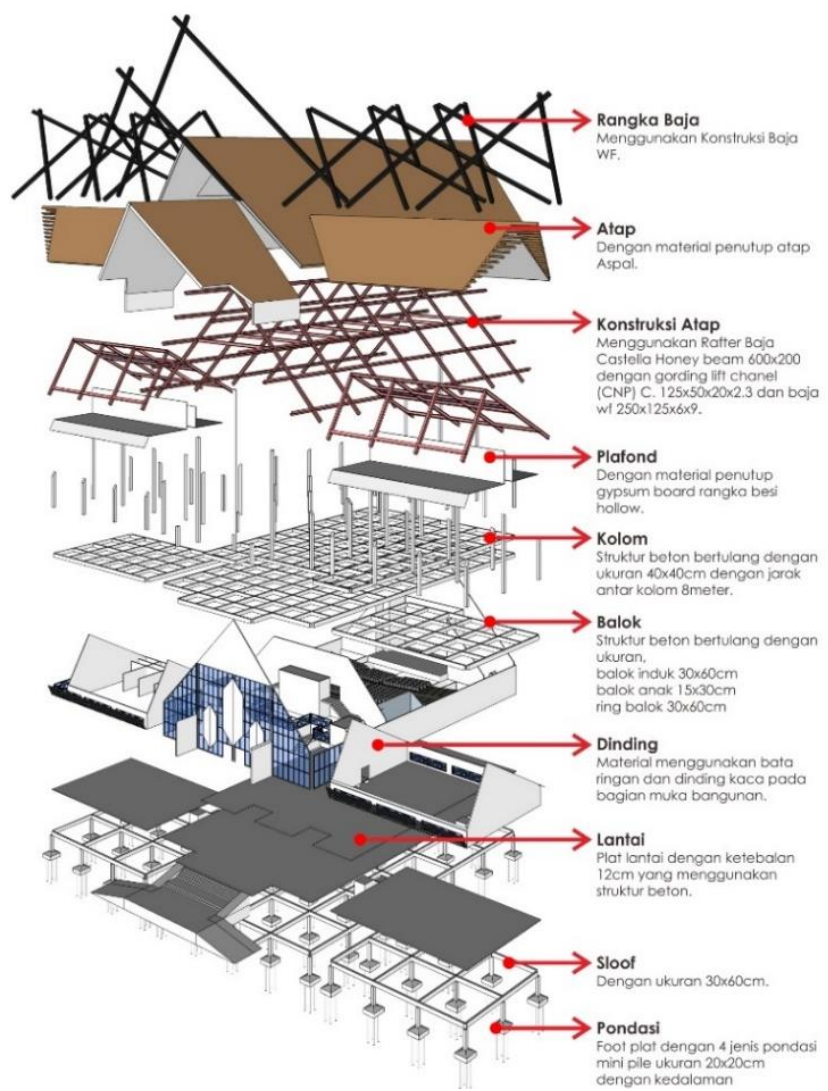

Gambar 24. Konsep Struktur

(Sumber : Analisa penulis, 2019)

Konsep utilitas
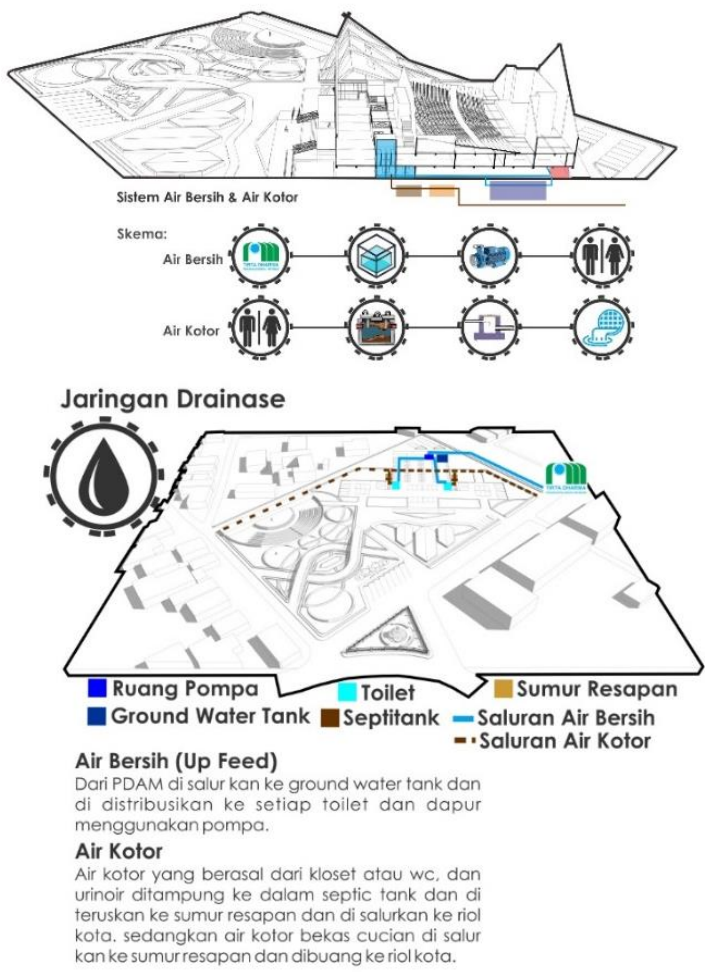

Gambar 25. Jaringan Drainase

(Sumber : Hasil Analisa 2019)

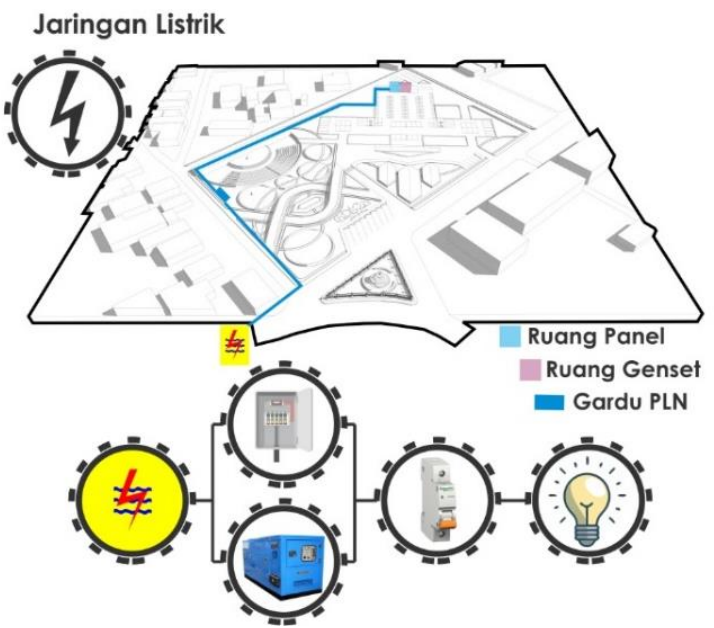

Gambar 26. Jaringan Listrik

(Sumber : Hasil Analisa 2019)
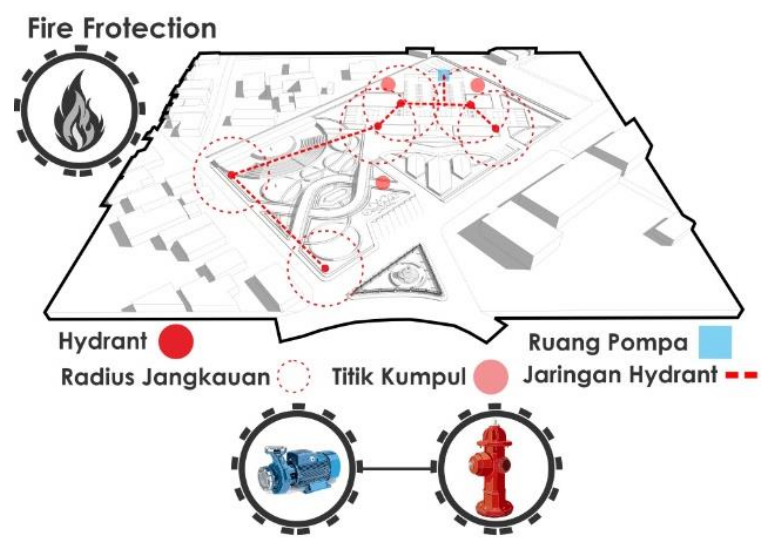

Gambar 27. Fire Frotection

(Sumber : Hasil Analisa 2019)

\section{Perspektif Bangunan}

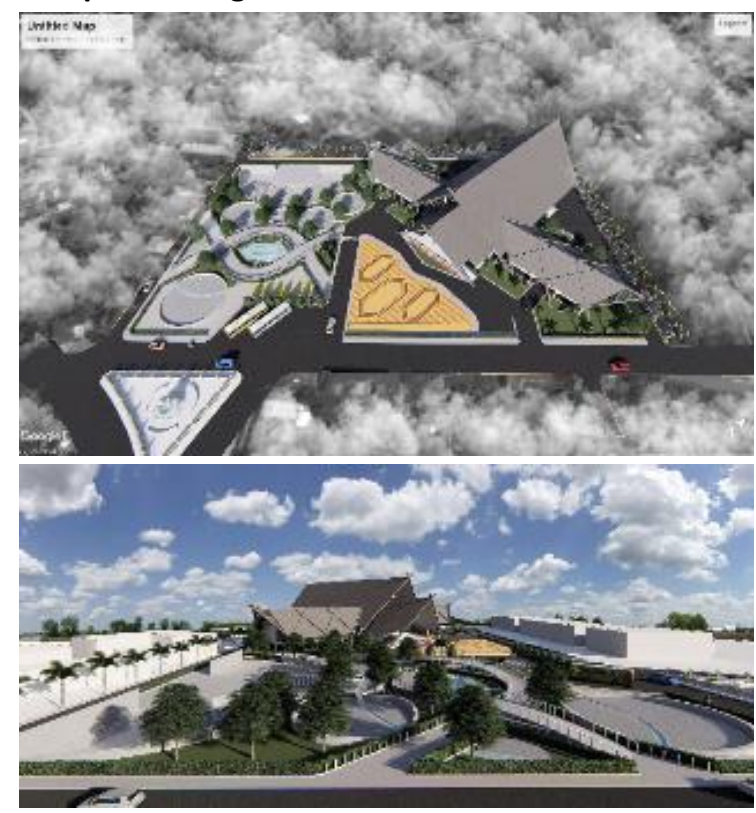

SINEKTIKA Jurnal Arsitektur, Volume 16 Nomor 2 Juli 2019 | 71 


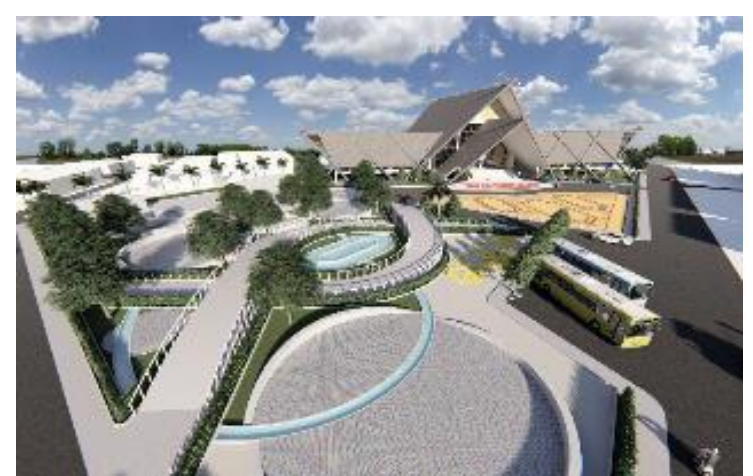

Gambar 28. Perpektif Areal View

(Sumber : Analisa penulis, 2019)

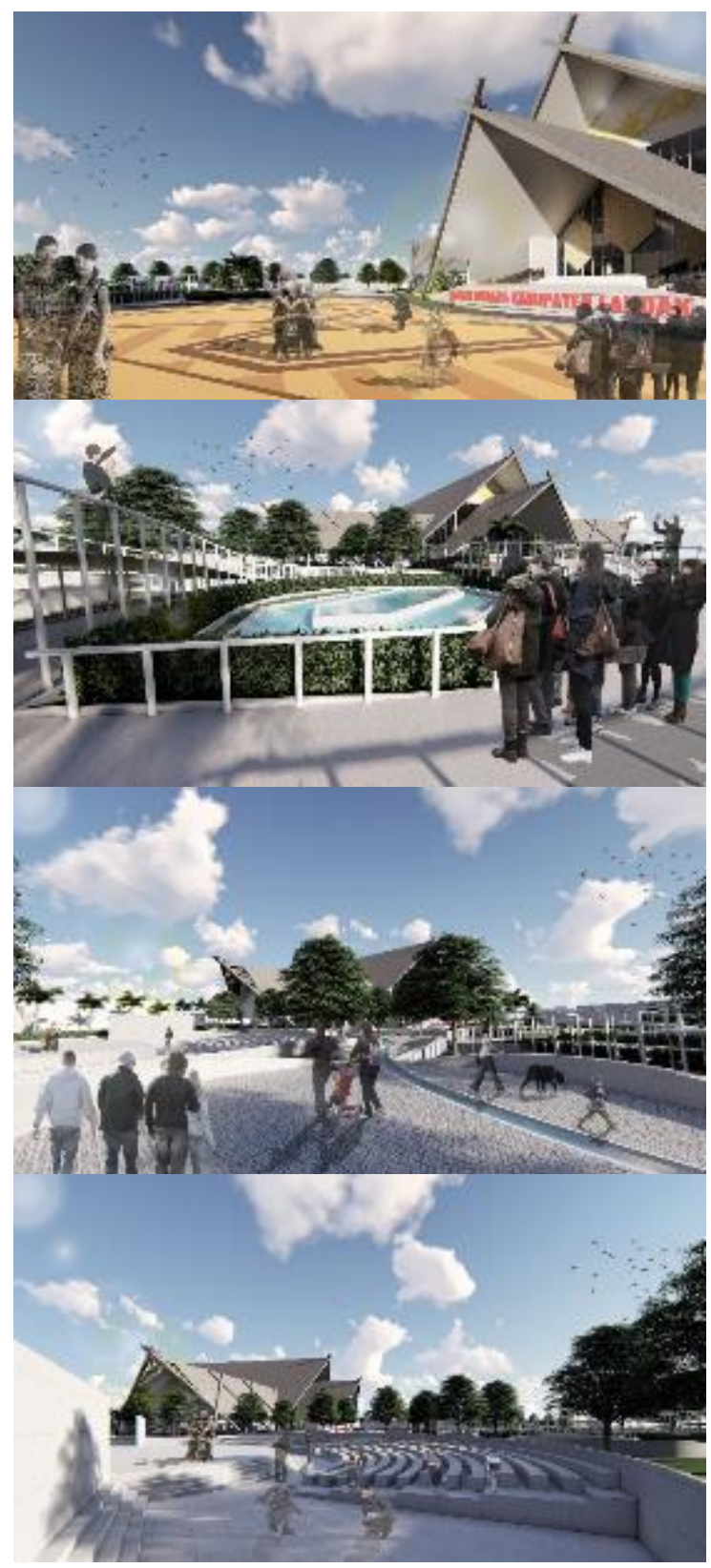

Gambar 29. Perpektif Normal View

(Sumber : Analisa penulis, 2019)

\section{KESIMPULAN}

Perancangan Taman Budaya Kabupaten Landak, Kalimantan Barat memiliki konsep mengangkat seni arsitektur lokal melalui pendekatan neo-vernakuler, selaras dengan fungsi bangunannya, untuk mewadahi semua kegiatan yang berkaitan dengan seni dan budaya yang ada di Kabupaten Landak. Keberadaan Taman Budaya bertujuan untuk menyadarkan masyarakat sekitar betapa pentingnya menjaga dan melestarikan kesenian dan kebudayaan daerah yang ada melalui desain lokal rumah Betang adat Dayak Kabupaten Landak Kalimantan Barat, yang didisain dengan pendekatan Neo-Vernakular. Disain Taman Budaya ini sangat diharapkan dapat meningkatkan Pariwisata Kabupaten Landak.

\section{DAFTAR PUSTAKA}

Krier, R. (2001). Komposisi Arsitektur (terjemahan). Jakarta: Erlangga.

Neufert, E, (2002). Data Arsitektur (terjemahan), Jakarta: Erlangga

Peraturan Pemda Kabupaten Landak No. 2 Tahun 2010, Tentang Rencana Induk Pembangunan Kepariwisataan Kab Landak.

Pemerintah Daerah Kabupaten Landak. 2013. Buku Putih Sanitasi Kabupaten Landak. Ngabang. Sekretariat Daerah

Sikula, Andrew E. (2011). Manajemen Sumber Daya

Manusia, Erlangga. Bandung 